\title{
ENTRE O UNO E O PLURAL: BREVES CONSIDERAÇÕES SOBRE PODER CONSTITUINTE E DIREITO DE RESISTÊNCIA A PARTIR DO CASO DO MOVIMENTO OCUPE ESTELITA
}

\author{
BETWEEN ONE AND THE PLURAL: BRIEF OBSERVATIONS ON \\ CONSTITUENT POWER AND ENDURANCE RIGHT TO MOVE THE \\ CASE OCCUPY ESTELITA
}

\begin{abstract}
${ }^{1}$ João Paulo Allain Teixeira
${ }^{2}$ Ana Paula Da Silva Azevêdo

\section{RESUMO}

O presente artigo discute a democracia agonística proposta por Chantal Mouffe a partir da compreensão da crise da democracia representativa com reflexos no esvaziamento do político, e a possibilidade de recuperação destes espaços por novas formas de manifestações sociais, como o caso do Movimento Ocupe Estelita, de Pernambuco. O texto analisa ainda o Poder Constituinte e a democracia representativa, destacando o papel de relevo que o Judiciário tem tido a partir do fenômeno da judicialização dos conflitos e, para efeito deste trabalho, do espaço político. Também se apresenta as bases conceituais utilizadas por Mouffe para construção da democracia agonística, a partir da crítica ao consenso fomentado por Rawls e Habermas, e a superação do antagonismo de Schimitt, na relação amigo x inimigo, pelo agonismo, na relação entre adversários. A partir desta inter-relação, é apresentado o movimento Ocupe Estelita bem como a sua pauta relacionada aos direitos urbanos, lançando as bases para aprofundamento da compreensão da dimensão do político no cenário brasileiro, tendo em vista as novas configurações dos movimentos.
\end{abstract}

Palavras-chave: Povo, Democracia representativa, Democracia agonística

\begin{abstract}
This article discusses the agonistic democracy theory proposed by Chantal Mouffe from the understanding of representative democracy crisis reflected in weakening the political and the possible recovery of these spaces for new forms of social events, such as the case of the Occupy Estelita Movement from Pernambuco (Brazil). The text also analyzes the constituent power and democracy, highlighting the important role that the judiciary has had from the legalization of the phenomenon of conflicts and for the purposes of this work, the political space. Also presents the conceptual basis used by Mouffe in order to build the agonistic democracy theory, from the criticism of the consensus promoted by Rawls and Habermas, and overcoming the antagonism Schmitt, in relation friend v. enemy, by agonism, the relationship between adversaries. From this interrelationship, the Occupy Estelita is presented as well as its agenda related to urban rights, laying the foundation for deepening understanding of the size of the Brazilian political scenario, given the new settings of movement.
\end{abstract}

Keywords: People, Representative democracy, Agonistic democracy

\footnotetext{
${ }^{1}$ Doutor em Direito pela Universidade Federal de Pernambuco - UFPE, Recife, (Brasil). Professor Adjunto na Universidade Federal de Pernambuco - UFPE. E-mail: tutortreinamento@gmail.com

${ }^{2}$ Mestranda em Direito pela Universidade Católica de Pernambuco - UNICAP, Recife, (Brasil). E-mail: tutortreinamento@gmail.com
} 


\section{INTRODUÇÃO}

O artigo discute a crise da democracia representativa a partir do modelo de democracia agonística proposta por Chantal Mouffe, atrelando a compreensão da crise aos seus reflexos no esvaziamento do político e a possibilidade de recuperação destes espaços por novas formas de manifestações sociais, como o caso do Movimento Ocupe Estelita, de Pernambuco.

Para construção do debate, o texto foi subdivido em três capítulos. No primeiro, desenvolve-se a análise sobre o poder constituinte e democracia representativa, lançando a discussão acerca do esvaziamento do político, envolvendo questões relacionadas ao poder do povo, representação e contenção. Também se analisa de forma perfunctória o fenômeno da judicialização dos conflitos relacionado à democracia representativa.

No segundo capítulo são aprofundadas as relações entre o esvaziamento do político, a judicialização do político e a crise da democracia representativa, tendo como referência a crítica formulada por Chantal Mouffe. Neste momento são apresentadas as bases conceituais utilizadas por Mouffe para construção da democracia agonística, a partir da crítica ao consenso fomentado por Rawls e Habermas, bem como a superação do antagonismo de Schimitt, da relação amigo x inimigo para a relação entre adversários, pelo agonismo, na relação entre adversários. Na mesma oportunidade, são destacadas as dificuldades de definição das regras do jogo democrático, e a possibilidade de utilização das ações coletivas disruptivas, que apesar de não serem reconhecidas institucionalmente, não podem ser prescindidas ou desconsideradas.

No ultimo capítulo apresenta-se o Movimento Ocupe Estelita, com atuação na capital pernambucana, e de sua pauta envolvendo direitos urbanos. São apresentadas suas formas de articulação e manifestação no cenário pernambucano, destacando a relação do mesmo com outros movimentos ao redor do mundo, e tecendo algumas reflexões preliminares acerca das novas possibilidades do espaço político na contemporaneidade.

\section{O PODER CONSTITUINTE E A DEMOCRACIA REPRESENTATIVA}

Repensar o espaço político a partir da crise da representação política no atual regime democrático na era da globalização tem sido temática recorrente de inúmeros autores que 
desenvolvem trabalhos relacionados ao campo político-social na contemporaneidade, partindo das mais diversas matrizes ideológicas.

No modelo contemporâneo de Estado Constitucional, quando se fala em democracia nos estritos termos da constitucionalidade da ação/anuência do povo, esse último no mais comum das vezes, é necessário localizar dentro dessa estrutura onde está o cerne de sua legitimidade. Ou seja, caberá descobrir o que ou quem legitima toda a ordem constitucional instituída muito bem protegida e controlada, e tida como representação última de uma democracia. No atual molde constitucional desvendar-se-á a resposta quando da inserção no âmbito da excepcionalidade de atuação do Poder Constituinte.

Portanto, cabe discutir inicialmente, a concepção de Poder Constituinte dentro da perspectiva constitucional, para em momento posterior analisar o papel designado permanente ao povo dentro do espaço democrático, no atual sistema de representação.

Deste modo, encontramos o Poder Constituinte nos autores constitucionalistas como poder ou força atrelada a uma de ideia de excepcionalidade, ao tratar de momento de eliminação ou criação de uma Constituição, entendida esta como lei fundamental da comunidade política (CANOTILHO, 1993, p.59). Como acrescenta Luís Roberto Barroso (1996, p.104) em relação ao seu caráter, o Poder Constituinte é revolucionário em suas raízes históricas e político em sua essência. Pelo exposto, a excepcionalidade repousa justamente no fato de significar uma ruptura com a ordem anterior e a construção de uma nova, semelhante ou não, mas que é representada por uma nova constituição.

O foco nesse instante volta-se à problemática de quem é o titular do Poder Constituinte. O questionamento atravessou vários momentos históricos e teóricos até alcançar o que hoje se denomina povo para o constitucionalismo, e por isso empregaremos uma maior profundidade. Nesses termos, analisemos a evolução da titularidade tomando por base a doutrina constitucionalista.

Comecemos com John Locke e o modelo inglês. Nele, o Poder Constituinte surge turvamente com a expressão "supreme power", com base em um estado de natureza em que está presente uma gama de direitos naturais anteriores a qualquer forma de governo. Como delineia Gomes Canotilho (1993, p.66), a doutrina entende que Locke sugeriu "uma distinção entre Poder Constituinte do povo reconduzível ao poder do povo de alcançar uma nova forma de governo" e o poder ordinário do governo e do Legislativo encarregados de prover a feitura e a aplicação das leis. O Poder Constituinte do povo é o poder supremo conferido à sociedade

\footnotetext{
1 "Poder supremo".
} 
ou a comunidade que por meio de um contrato social consente ao poder supremo do Legislativo poderes limitados e específicos dentro dos moldes da representatividade no corpo de um Parlamento forte. Ou seja, em conformidade com as liberdades inatas e inalienáveis as quais chama de direitos naturais. Ressalte-se que supreme power e o povo ao qual Locke se refere como seu titular estão intimamente ligados a uma concepção de direito de resistência (NEGRI, 2002, p.209) e principalmente aos direitos sobre a propriedade frente ao Estado. O contrato ilustrado por Locke remonta à Magna Carta Libertatum ${ }^{2}$ de 1215 e a Revolução Gloriosa, numa antecipação do que levará séculos a frente, e com o modelo norte-americano, ao constitucionalismo. No entanto, nesse momento, não a Constituição, mas o próprio Parlamento entendido como constituição viva representa o centro do sistema.

Já na França, tem-se Emmanuel Sieyès. Por meio dele alcança-se o Poder Constituinte destarte Pouvoir Constituant, atrelado ao momento revolucionário francês de transformação da ordem monárquico-absolutista vigente até então. Nesse sentido, Sieyès invoca a Nação como titular do Pouvoir Constituant, sendo originário e soberano, com o intuito de derrubar e reorganizar a ordem nacional. Entretanto, para a compreensão da proposta de Sieyès, é necessário pincelar algumas das ideias rousseaunianas de soberania popular e vontade geral. Rousseau volta-se à maioria como titular da soberania - essa expressão deve ser aproximada da concepção de Poder Constituinte - ou seja, para ele se é livre segundo as leis construídas pela maioria, pois é como se o indivíduo, isoladamente considerado, houvesse elaborado a própria lei e não caberia a partir de tal ato descumpri-la (BINENBOJM, 2001, p.20). Dentro desse liame, o titular do Poder Constituinte rousseauniano é a vontade geral, reduzindo as diferenças à unidade. Esse gancho é percebido por Sieyès e usa-o juntamente com a representatividade lockeana para alcançar a Lei Fundamental. Dito de outro modo, Sieyès relativiza a soberania popular rousseauniana fazendo-a atuar canalizada nos moldes de Locke de escolha dos representantes do Poder Constituinte agora como representantes da vontade geral pautado em uma Lei Fundamental que pode ser facilmente absorvida como uma constituição.

Encontra-se, portanto, em Sieyès, a configuração do Pouvoir Constituant e Pouvoir Constitué - Poder Constituinte e Poder Constituído, respectivamente - e o Princípio da Supremacia da Constituição. Os três institutos reunidos resultam na soberania da Nação que transcende a todos os seus elementos. Se o Pouvoir Constituant voltava-se a derrubada do regime monárquico-absolutista e a instauração de uma nova ordem pelo Poder constituído (ou

\footnotetext{
${ }^{2}$ A Magna Carta de 1215 da Inglaterra, uma verdadeira espécie de contrato entre os proprietários de terra ingleses e o rei João Sem-terra.
} 
derivado), derivado da vontade geral, não caberia mais, desse modo, a atuação da matriz, uma vez conquistado o objetivo, por significar fonte de grande instabilidade à ordem. Daí, em última análise, a superação entre Pouvoir Constituant e Pouvoir Constitué culminar na constituição e na soberania da Nação: "mais valia um freio do que uma insurreição permanente" (SIEYÈS apud CANOTILHO, 1993, p.68).

Num retrospecto, em Locke o Poder Constituinte é o poder de resistência fundado na expressão contratual no intuito primeiro de criar barreiras entre o povo proprietário e o parlamento como representação daquele e manutenção da ordem. Em Rousseau, tem-se o apelo democrático de redução da multiplicidade à unidade na figura da vontade geral e soberania popular, como também em Sieyès, em que há a mistura das duas perspectivas instrumentalizando primeiramente a vontade geral para a derrubada do regime indesejado e transferindo sua força a um poder constituído sob o império da constituição na qualificação de soberania da Nação. Analisemos, então, o momento constitucionalista do Poder Constituinte, na chamada Teoria do Poder Constituinte. Tal instante remonta a Revolução Americana onde se imbuem poder constituinte, poder constituído e constituição numa proposta de republicanismo democrático.

$\mathrm{Na}$ famosa expressão do preâmbulo da Constituição Norte-americana - "we the people"3 - o povo é colocado como o titular do poder constituinte juntamente com a determinação de seus espaços de atuação, limitação e finalidade. Assim, trata-se do corpo político com a clara missão de criar a constituição e, uma vez cumprida a meta, é afastado de todo o processo tornando-se a criatura maior que o criador. O povo sai do eixo central e a constituição o assume como representação última daquele. Como bem enumera Canotilho (1993, p.64), a constituição, por sua vez, dentro da República Democrática norte-americana tem por finalidade o registro de um conjunto de regras invioláveis em que se afirma:

a) a idéia de "povo" nos EUA como autoridade ou poder político superior; b) subordinação do legislador e das leis que ele produz às normas constitucionais; c) inexistência de poderes "supremos" ou "absolutos", sobretudo de um poder soberano supremo, e afirmação de poderes constituídos e autorizados pela constituição colocados numa posição equiparada e equilibrada; d) garantia, de modo estável, de um conjunto de direitos plasmados em normas constitucionais, que podem opor-se e ser invocado perante o arbítrio do legislador e dos outros poderes constituídos.

De logo se depreende que a concepção de poder constituinte lançada pelo constitucionalismo norte-americano é colocada como poder fundador de uma nova ordem

\footnotetext{
3 "Nós, o povo".
} 
constitucional em um dado momento de excepcionalidade, traçando parâmetros fundamentais de cerceamento e controle de todas as esferas do sistema no sentido garantístico de Estado, ou seja, na finalidade de garantir direitos e limitar poderes na acertada expressão de sistema “checks and balances". Note-se que as limitações dizem respeito principalmente a atuação do poder político dentro da constituição e o controle de constitucionalidade referem-se justamente a manutenção da ordem, das instituições e do povo, acomodado em seu cevado espírito de importância.

Pelo exposto, limita-se o poder constituído e guarda-se com adoração o momento extraordinário da construção da então nova ordem, que foi o constituinte. Mas dentro do sistema republicano há ainda a divisão de Poderes: Legislativo, Executivo e Judiciário. O Legislativo é o primeiro e mais contundentemente limitado, pois ao analisá-lo dentro da moldura, trata-se de um poder constituinte permanente ainda que derivado, em oposição ao originário fundador. Fica ele cercado de procedimentalismo e formalismo quando de sua atuação, tão somente em casos excepcionais pode modificar a Constituição. Quem afronta a Constituição está em primeira instância afrontando o povo, mesmo que seja o próprio povo quem a afronte. $\mathrm{O}$ que definitivamente não ocorre com as demais esferas, especialmente a Judiciária, mas o tema será discutido no próximo item, cabendo identificar agora quem é o povo, termo tão largamente utilizado nos países e constituições como base da legitimidade democrática, nesse esteio, "o poder constituinte não é negado, mas desfigurado num desenvolvimento que lhe renega a gênese" (NEGRI, 2002, p.274)

Friedrich Müller (1998) dedica um livro inteiro a esse questionamento sobre o povo como titular do poder constituinte e fundamento do sistema democrático vigente, utilizar-nosemos de tal obra para analisá-lo.

Müller (1998, p.7) aponta quatro óticas sobre a interpretação da expressão povo dentro do discurso democrático atual: a) povo como instância global de atribuição de legitimidade; b) povo ativo; c) povo destinatário as prestações civilizatórias do Estado e; d) povo ícone. As acepções de Müller (1998, p.44), como o próprio afirma, não se tratam de acepções propriamente ditas, tão-somente formas de manipulação. Tanto o é que há certa dificuldade em discerni-las posto se imbuírem de tal maneira no discurso democrático hodierno que funcionam todas com a finalidade de dar legitimidade ao sistema e de apartar a participação do mesmo povo tal constantemente invocado, com a exceção dos espaços legitimados préestabelecidos, tornando qualquer tentativa débil e infundada dentro da retórica democrática. Contudo, em linhas gerais, o povo como instância de atribuição deve ser entendido como legitimador da ordem vigente. 
Assim, o conceito é instrumentalizado e positivado como base sobre a qual se edifica o sistema e não se pode ser questionada sua validade, está ligado ao conceito de cidadania, de nacionalidade. O povo ativo vincula-se a noção de eleitores, ou seja, aqueles que diretamente têm competência para a escolha programada e praticamente irrevogável do corpo de representantes que funcionaram como o corpo de mediação e legitimidade democrática. As eleições são, sem dúvida, a base dessa perspectiva, mas também podemos enquadrar outros prédeterminados casos expressos em lei, e nos estreitos termos desta, em que os eleitores podem movimentar-se, a exemplo da iniciativa popular, do referendo e do plebiscito definidos constitucionalmente no Brasil (art.14). Aqui o sufrágio universal é utilizado como meio para o exercício da soberania popular.

Dentro da mesma ótica, prossegue o já referido autor com o povo como o povo destinatário, tendo a vantagem, em relação aos demais já mencionados, de abranger um número bem maior de pessoas, posto que não o determina em termos de procedimentalismo normalizado com uma série de requisitos. Entretanto, recai na retórica de um discurso democrático que ao mesmo passo que inclui o povo dentro dessa terminologia genérica, acaba por excluí-lo, pois o afasta concomitantemente, inviabilizando qualquer reação e resistência, retomando para isso todas as outras formas de compreensão do uso da palavra povo. Esclareçamos: se o destinatário é o povo, considerado indistintamente, as ações são voltadas para ele, com o objetivo de atender suas necessidades analisadas e formuladas por seus representantes, escolhidos diretamente pelo sufrágio universal (povo ativo), legítimas e legitimadas pelo povo (povo como instância de atribuição) desde sempre e inquestionáveis, portanto, por serem fruto da vontade geral (povo ícone), ou ainda pela via indireta do Judiciário - em nome, para e pelo povo.

Alcança-se, agora, a manobra que Müller (1998) identificou sob o nome de povo como ícone. Um transcendentalismo forjado, diminuindo e não raro ocultando uma força que é real e não transcendental. O povo para servir de base para a retórica democrática deve ser, para tanto, destituído de seu caráter naturalmente ameaçador para a ordem vigente. Assim, trata-se de um recurso metafórico que é usado para invocar e legitimar a democracia completamente desprovida de feição, de alcance, de força, uma palavra jogada ao vento, contudo, uma palavra soberana. Remete-nos, de logo, a divinização dos antigos monarcas que representavam a um só tempo o divino e o terreno, no entanto, essa nova forma de divinização só é invocada para legitimar as ações dos poderes instituídos ou derivados. O povo funciona como instância última e primeira ao mesmo tempo em que não existe materialmente, somente operacionalmente através dos sistemas jurídicos. 
Detendo-nos a terminologias, a Nação perdeu muito em força frente ao povo pela dificuldade de manejamento do termo. Na época da Revolução Francesa e todo o espírito que a envolveu, o conceito de Nação utilizado astutamente por Sieyès - relembrando o Pouvoir Constituant - buscou, sobretudo, alavancar na França uma necessidade de mudança e ruptura com o regime monárquico-absolutista que não poderia se submeter teoricamente a divisão de classes ou explicações sobre o alcance do termo povo. A dificuldade de apontar quem era o povo na época da Revolução se mostrou superada com a adoção da Nação como sujeito. De tal forma, acima da vontade da burguesia, da plebe e do clero estava incólume a figura da soberana Nação Francesa, baseada na vontade geral e representação. Curiosamente, a mesma dificuldade que foi apontada à adoção de povo enquanto sujeito na França em meados do século XVIII, foi um dos principais critérios para a escolha do povo pela teoria constitucionalista de fundamento democrático. Nesse novo momento, Nação remete a questões de sangue e território, incompatíveis com a proposta de globalização. Como foi observado, depreende-se facilmente o quão obscuro pode ser tal conceito. Povo é um conceito extremamente relativo, contudo, uno. Eis a chave para o retórico discurso democrático.

Pelo exposto, o povo torna-se o sujeito da democracia, e a soberania, por sua vez, o seu poder de expressão. Traçada uma perspectiva geral sobre o povo, analisemos a concepção de soberania. Assim, a soberania pode ser enxergada sob dois ângulos: soberania do Estado e soberania no Estado, como aponta o trabalho de Ronaldo Guimarães Gallo (2006, p.39). O primeiro diz respeito ao Estado como soberano frente a outros Estados, essa soberania de fato vem sendo solapada pela interação cada vez maior entre os Estados soberanos e as transformações do mundo, principalmente no concernente ao direito internacional. Já a segunda, a soberania no Estado, está ligada a delimitação da autoridade superior dentro do Estado e principalmente ao seu sujeito, seu titular (BONAVIDES apud GALLO, 2006, p.39).

A soberania no Estado é a que mais se faz necessária ser entendida para o prosseguimento da pesquisa, e fixar-nos-emos, ainda, ao eixo das doutrinas democráticas: a soberania nacional e a soberania popular. A soberania nacional remonta a Revolução Francesa e a Teoria do poder Constituinte de Sieyès, assim sendo, como já discutido, a soberania não pertence ao povo, e sim à Nação, entendida como o corpo político que detém e exerce a soberania por meio de seus representantes que são escolhidos pelo povo. Por seu turno, a doutrina da soberania popular coloca o povo como o detentor da soberania e é a mais acatada nos sistemas e constituições atuais. Nesse sentido, Paulo Bonavides (apud GALLO, 2006, p.40) expõe: 
[A soberania popular é] tão-somente a soma das distintas frações de soberania, que pertencem como atributo a cada indivíduo, o qual, membro da comunidade estatal e detentor desta parcela do poder soberano fragmentado, participa ativamente na escolha dos governantes.

Analisado o exposto, tanto a doutrina que coloca a Nação como sujeito titular da soberania como a que posiciona o povo, entendido enquanto soma, representam, cada uma a seu modo, aquilo que é a base da concepção de soberania: a unidade, e para a unidade da soberania como expressão de poder, sujeitos igualmente unos, seja a Nação ou o povo. Ressalte-se a importância dessa observação, pois dela emergirá a maior crítica negriana à lógica da democracia real e das estruturas dos sistemas constitucional-democráticos hodiernos. Nesse sentido, da soberania enquanto unidade, posiciona-se Hermann Heller (apud GALLO, 2006, p.36):

A soberania é a qualidade da independência absoluta de uma unidade de vontade frente a qualquer outra vontade decisória universal efetiva. Este conceito, em seu aspecto positivo, significa que a unidade da vontade a que corresponde a soberania é a unidade decisória universal suprema dentro da ordem de poder de que se trate. ${ }^{4}$

Por essa perspectiva, somente o uno pode governar, seja com o nome de Nação, de povo, de vontade geral, e desde que mediado por um sistema de representação que se torna, retoricamente, juntamente a soberania do uno, os pilares da democracia real.

\section{A DEMOCRACIA AgONÍSTICA E A CRISE DA REPRESENTAÇÃo POLÍTICA: O ESPAÇO DO PLURALISMO E DO CONFLITO}

A democracia real baseada no povo genericamente entendido enquanto vontade geral mediatizada, dividida e temporalizada marca a realidade da sistemática hodierna, onde a soberania é a expressão de seu poder reconhecido pelas constituições, que tem emergido e se afirmado a fonte máxima da soberania do Estado como exteriorização da vontade do povo.

De outra banda, altera-se completamente o eixo do debate político social,

\footnotetext{
${ }^{4}$ Originariamente, HELLER (1965, p.197) apud GALLO (2006, p.36): "la soberania es la cualidad de la independencia absoluta de una unidad de voluntad frente a cualquiera otra voluntad decisoria universal efectiva. Este concepto, en su aspecto positivo, significa que la unidad de voluntad a la que corresponde la soberania es la unidad decisoria universal suprema dentro del orden de poder de que se trate". Trad. livre.
} 
consubstanciado a partir do conflito entre representantes e representados com embates envolvendo legitimidade, para se ter o conflito reduzido a uma decisão de um terceiro Poder, o Judiciário, não representativo, reforçando o movimento de judicialização de conflitos, e sobretudo, judicialização do político, que reforça a práxis da disputa individualista, e não coletiva, da democracia contemporânea.

A judicialização do político é diuturnamente fomentada. Ao povo não é razoável admitir ocupação de ruas e praças, incomodando a coletividade e os mandatários eleitos periodicamente, quando o espaço indicado pela Constituição e pela práxis é a ocupação de salas de Fóruns e Tribunais de todo o país, não raro tendo o mesmo Poder Judiciário avocado para si a competência para realização de audiências públicas típica de órgão Legislativo, entendida a competência para "convocar audiência pública para ouvir o depoimento de pessoas com experiência e autoridade em determinada matéria, sempre que entender necessário o esclarecimento de questões ou circunstâncias de fato, com repercussão geral e de interesse público relevante" ${ }^{, 5}$. Desloca-se o centro do debate para um poder de contenção.

Novamente, o povo é limitado, pois a partir do momento em que determinada pauta passa a ser judicializada, o descumprimento da ordem judicial possui poder diverso daquela atribuída aos representantes do povo (Executivo e Legislativo).

Neste contexto, de reconhecimento de uma democracia como fonte de permanente conflito e pluralidade, tem-se a reflexão de Chantal Mouffe, para quem a sociedade democrática trata-se de "uma esfera pública vibrante onde muitas visões conflitantes podem se expressar e onde há uma possibilidade de escolha entre projetos alternativos legítimos" (MOUFFE, 2003). Em uma rápida análise já é possível supor que o Judiciário não se apresenta como o espaço mais propício a criação e fomento dos debates no seio político, quando o mesmo almeja o encontro do consenso a partir de uma decisão fundada na racionalidade.

O projeto democrático tal como é apresentado na contemporaneidade traz arraigada a sua práxis uma concepção de consenso abstrato fundada na interpretação universal de valores, que podem congregar todos os desejos, um projeto de sociedade pacificada, sem conflitos, aliada a uma perspectiva de racionalidade e individualismo, que já não se mantem estabilizada. O alcance do bem comum, justiça e da paz social, por exemplo, são expressões corriqueiramente utilizadas na esfera do Judiciário para justificar a resolução de conflitos sob o pretensioso argumento de utilização de critérios de racionalidade que se julgam universais.

\footnotetext{
${ }^{5}$ Leis 9.868/1999 e 9.882/1999 e no STF, a Emenda Regimental 29/2009, segundo os arts. 13, XVII, e 21, XVII, do Regimento Interno.
} 
Todavia, as manifestações populares que tem ocorrido em todo mundo, em exemplos como da Primavera Árabe, ocupações de praças na Grécia, Londres, Françam Nova Iorque e mesmo no Brasil, sob os mais diversos signos, dão conta da fragilidade do sistema de representação política no modelo democrático vigente na sociedade ocidental. Viver a contemporaneidade tem sido um convite ao estudo de propostas de superação da crise, que escolhemos analisar no presente trabalho a partir da autora Chantal Mouffe e seu modelo de democracia agonística, onde ganha especial relevo a ideia de reconhecimento das relações de poder e da superação do antagonismo pelo agonismo na formação de identidades coletivas, como pluralidade agonística.

Partindo de concepções pós-marxistas, a autora belga faz ponderações relevantes ao contexto ao qual estamos inseridos, na era da globalização, envolvendo questões como a superação de luta de classes e crise do marxismo, a reconfiguração das concepções tradicionais de "esquerda" e "direita", a derrocada dos regimes totalitários no Ocidente, do triunfo da racionalidade sobre as paixões, onde tece críticas à evasão do político associando-a a compreensão de racionalidade, individualismo e universalidade e a incessante busca pelo consenso como fundamento para a Justiça na contemporaneidade (MOUFFE, 1999).

A proposta de Mouffe (2003, p. 15) se distingue na medida em que não pretende o esvaziamento do poder e da obtenção do consenso, a partir do pressuposto de que as relações de poder são constitutivas do social, e assim sendo, a política democrática deve voltar-se à construir formas de poder que sejam compatíveis com valores democráticos, não negar-lhes conhecimento ou força-lhes a dissolução.

Para tanto, dedica boa parte de seu livro intitulado El Retorno del Politico para analise dos trabalhos de Jürgen Habermas e John Rawls, onde tece diversas críticas voltadas à concepção da filosofia política sem política, na medida em que o conflito é afastado do centro dos debates para alcance de um consenso pautado em um ideal racionalista.

Neste sentido, a autora compreende como fundamental apresentar a distinção entre dois tipos de categorias utilizadas em sua obra, quais sejam, "o político" (Political) e "a política" (Politics):

Por "político" refiro-me à dimensão do antagonismo que é inerente a todas as sociedades humanas, antagonismo que pode assumir formas muito diferentes e emergir em relações sociais diversas. "Política", por outro lado, refere-se ao conjunto de práticas, discursos e instituições que procuram estabelecer uma certa ordem e organizar a coexistência humana em condições que são sempre potencialmente conflituosas, porque afetadas pela dimensão do "político". (MOUFFE, 2003, p. 15) 
A partir de Carl Schimitt - autor sobre cuja obra discorre no capítulo intitulado Pluralismo y democracia moderna - e de sua concepção de antagonismo, fundada na relação amigo x inimigo no campo da política, Mouffe desenvolve a sua teoria voltada ao agonismo, onde propõe a superação desta dicotomia para inserir a concepção de adversários. Para ela o adversário é o inimigo legítimo dentro do espaço democrático onde o consenso inicial - que podemos considerar como sendo as regras do jogo - é exteriorizado por meio de princípios ético-políticos aceitos por ambas as partes, ainda que lhes sejam dados alcances e interpretações divergentes.

Sob este prisma, a existência de acordos pode ocorrer e ocorrerá no processo democrático, contudo, os acordos/consensos deixam de ser o objetivo do espaço político para acontecer de forma contingencial, conquanto a essência da democracia é o conflito, vez que toda ação de força preponderante em determinado contexto traz consigo uma ideia de hegemonia, ainda que provisória, e toda hegemonia traz consigo a ideia de exclusão que não pode ser dirimida se utilizando do argumento do consenso. $\mathrm{O}$ adversário vence, mas apenas a batalha, e reconhecer a relação de poder envolvidas no alcance do "consenso" implica reconhecer e afirmar os movimentos internos, permanentes e legítimos de insurreição (MOUFFE, 1999).

Retomar, portanto, a ideia de polis e polemos é crucial para compreensão da dimensão do político, sob a perspectiva da autora, de tal forma, que a própria fragilização da democracia na atualidade pode ter como causa a ausência de uma esfera pública capaz de possibilitar a confrontação agonística proposta por Mouffe. Não existe campo para o debate, somente o reforço à intermediação, ora pela representação, ora pelo Judiciário.

No contexto, o Judiciário surge como sendo o responsável - na condição de terceiro imparcial - para aplicar a Lei e prover soluções para todos os tipos e conflitos, inclusive os que deveriam pertencer ao espaço político, numa perspectiva diferenciada, inclusive, da própria divisão interna de competências e atribuições entre os três Poderes, dos quais unicamente o Judiciário se apresenta como sendo poder não derivado da representação democrática.

A realidade brasileira, conforme antecipado alhures, não é destoante, onde pelo fenômeno da judicialização cada vez mais conflitos são levados à arena de deliberação do Poder Judiciário e não mais aos espaços públicos de participação popular. Em outra mão, aumentam os atos do Legislativo e do Executivo voltados a tolher o espaço de manifestação pública, utilizando-se, não raro, do braço forte do Estado referente ao Direito Penal, por meio 
da criminalização de condutas tidas como usais em manifestações públicas de resistência.

A crítica de Mouffe é tecida no sentido de que ao assumir o conflito como inerente ao regime democrático, reforça-se que para cada consenso estabelecido há necessariamente uma exclusão, um dissenso em paralelo ao consenso vencedor que não se dissipa, apenas reconhece a perda da vitória naquela circunstância. Assim, o discurso hegemônico precisa do não hegemônico para sua afirmação, algo que se afirma em relação ao outro, e não em si mesmo.

Desta forma, as forças dissidentes se tornam conscientes da exclusão ao mesmo passo o fato de não ter levado a vitoria não implica o afastamento da esfera pública, mas a sua permanência, como contraditório. Para a autora, não há como cobrir a democracia e o campo das paixões sob o véu da racionalidade ou da moralidade, disfarçando-se (ou tentando disfarçar) a relação de forças existentes, onde provisoriamente uma surge como hegemônica.

A pluridade agonística - outro conceito formulado por Mouffe baseado na ideia de alteridade - esteia-se no "reconhecimento da multiplicidade de cada um e das posições contraditórias a que esta multiplicidade subjaz" (MOUFFE, 2003, p. 29), não apenas em ato de tolerância do outro, mas de valorização do outro, considerando que a sua inexistência impede a minha afirmação como identidade. Assim, da mesma forma que a democracia agonística deve ser compreendida como dissenso, a construção das identidades coletivas igualmente pressupõe o debate e o agonismo, na medida em que a construção da esfera pública se dá a partir da celebração do conflito, e não de sua eliminação, possibilitando a escolha entre alternativas efetivamente reais.

Reconhecer o outro como opositores legítimos implica em tratá-los "como pessoas cujas ideias são combatidas, mas cujo direito de defender tais ideias não é colocado em questão" (MOUFFE, 2005, p. 20), destacando-se a impossibilidade de resolução racional do conflito em um campo dominado pelas paixões, como o político, algo que consenso e a perspectiva de universalidade de um discurso não pode apreender: de um lado tem-se a adesão aos princípios éticos-políticos; de outro discorda-se em relação ao sentido e implementação destes princípios.

A ideia da autora é fundamental para compreensão da crise da representação política, muito em razão da inexistência de apresentação de conflito dentro de nosso regime, seja na arena pública ou mesmo nos espaços de representação. Os próprios projetos dos partidos políticos, expressão máxima do pluralismo político insculpido no texto constitucional, denotam o esvaziamento do político por meio da negação do conflito e assim, pela inexistência do debate, igualmente se esvaziam como identidades coletivas que necessitam do 
outro para se afirmar, ocasionadas, sobretudo, pelo estigma do "consenso ao centro".

De outra mão, Mouffe lança as bases para compreensão de que uma vez não sendo as paixões mobilizadas no espaço do político, onde se encontrariam adversários submetidos ao mesmo conjunto de princípios éticos-políticos, aos quais seriam as regras do jogo democrático, dá-se azo à canalização destas paixões para movimentos fundamentalistas, voltados a "demandas particularistas, questões morais inegociáveis ou partidos populistas anti-establishment" (MOUFFE, 2003, p.20), tornando a ausência de um espaço político dinâmico um terreno fértil para o crescimento de fundamentalistas das mais variadas ordens (étnica, religiosa, nacionalista).

Uma democracia em bom funcionamento demanda um embate intenso de posições políticas. Se faltar isso, há o perigo de que a confrontação democrática seja substituída por uma confrontação dentre outras formas de identificação coletiva, como é o caso da política da identidade. Muita ênfase no consenso e a recusa de confrontação levam à apatia e ao desapreço pela participação política. Ainda pior, o resultado pode ser a cristalização de paixões coletivas em torno de questões que não podem ser manejadas [managed] pelo processo democrático e uma explosão de antagonismo que pode desfiar os próprios fundamentos da civilidade. (MOUFFE, 2005, p.21)

Nada mais representativo do que a conjuntura do cenário político nacional, com o crescimento de pautas cada vez mais fundamentalistas, avançando para as pautas de grupos de minorias ${ }^{6}$, ou mesmo contra o próprio regime democrático, com a articulação popular voltada ao retorno da Ditadura Militar, com pautas de extrema-direita.

Neste contexto, é que Mouffe (1999a) sugere o desenvolvimento da democracia a partir do oferecimento de alternativas ao neoliberalismo no cenário de globalização, marcado pela revolução da informação e modificação na relação de trabalho, comumente relacionado ao trabalho imaterial, com o crescimento da comunicação em rede em escala global.

A crise da representação política e da democracia transcende aos limites do Estado brasileiro, assim como as redes de resistências, e a finalidade primeva da política democrática é reconhecer e afirmar a existência de paixões, sem negá-las ou relega-las à esfera privada, levando-as ao centro da cena do pluralismo agonístico (MOUFFE, 1999a).

O corpo político desse sistema como continuamente afirmado é o povo, concomitantemente soberano e tutelado. O que parece confuso tornar-se-á claro quando admitimos a soberania como expressão da força do uno, e por isso também una, e limitada. Se há de se descrever a soberania, dois adjetivos se fazem indispensáveis, ela é una e limitada.

\footnotetext{
${ }^{6}$ Relacionados a LGBT ou Religião de matrizes africanas, apenas como exemplo.
} 
Una, como já discutimos, porque não há de se admitir o poder descentralizado, plural, somente o uno pode governar. O poder deve ser, portanto, soberano. E limitada, pois é uma via de mão dupla, ressaltando que o fluxo nem sempre é eqüitativo, em uma mão os deveres e na outra, os direitos. No sistema dos "checks and balances", a soberania popular não pode ser absoluta "porque a idéia de um poder supremo e incontrastável representa aquela hybris, que a sabedoria grega sempre considerou a matriz da tragédia humana" (COMPARATO apud MÜLLER, 1998, p.28). De tal sorte que não somente a soberania popular centrada na figura do poder originário do povo, mas também a soberania do poder derivado do povo, em termos de representação, principalmente, na figura do Legislativo, também é limitada.

O povo destituído de seu poder ou, no mínimo, "inconscientizado" dele, vem desacreditando da representação povo-legislador como ponte necessária entre ele e a democracia tão largamente aclamada. Não nos faltam exemplos atuais para relembrar o quão solapada tem sido a relação povo-Legislativo: corrupção, conchavos, acertos obtusos, todos eles abalando consideravelmente e quiçá irreversivelmente o sistema democrático- representativo. No entanto, ao invés de tomar as rédeas da situação, o povo, talvez pelo fato de constitucionalmente o poder emanar dele e não residir nele, agarrou-se a outra espécie de democracia representativa, reconhecendo a impropriedade do termo democracia quando esta se dá apenas mediante votos periódicos.

Em decorrência da crise da democracia-representativa na figura do Legislativo, talvez já previsivelmente, o Judiciário assumiu o seu papel. A constituição aclamada representação máxima do povo é colocada no topo da estrutura. Sua efetivação e defesa constituem a própria vontade e corpo do povo, e o Judiciário, constituidamente, detém essa competência. O povo a instituiu. Percebe-se que apesar da representação ter trocado de eixo, a base da retórica continua a mesma. Porém, o transcendentalismo que tal mudança causa abate ainda mais profundamente a função do povo dentro da prática - não no discurso democrática. Num primeiro momento, o esvaziamento do espaço de discussões e decisões do povo é deslocado para os gabinetes das instâncias judiciais, do qual resulta também o individualismo de algo - democracia - que em essência é coletivo. De outra perspectiva, dada a importância da matéria da qual trata a constituição, o povo não seria capaz de deliberar a respeito, o que obriga a um corpo letrado decidir pelo povo como seu tutor constitucional nos conflitos que o circundam cotidianamente. O Judiciário, por todo o exposto, encarrega-se de aplicar e proteger a Constituição ainda que quem a questione seja o povo, pois os juízes saberão escolher o melhor para ele e ainda, a certeza da escolha dá-se com mais razão por essa esfera contar com vários graus de decisão. 
Em síntese, o fundamento da democracia real é a homogeneização do sujeito titular de um poder limitado, que a permite a um só e mesmo tempo legitimar-se com a anuência do povo e excluí-lo de sua prática. Mas o povo volta reclamar o seu espaço, inclusive o retorno do político de Mouffe (1999) traz em sua obra traz muito das novas demandas deste novo século.

Contudo, o debate dentro dos mecanismos institucionalizados não parece tarefa das mais fáceis, muito em razão de as regras básicas para o jogo democrático não serem objeto de consenso, nem mesmo o elementar, apregoado por Mouffe. Assim é que, apesar de se reconhecer existir o conflito, o espaço do antagonismo se parece mais representativo das disputas no espaço político, sobretudo a partir de estratégias disruptivas, fora da institucionalidade estabelecida, do que o agonismo proposto por Mouffe.

A crítica volta-se a considerar que apesar da democracia agonística de Mouffe consistir uma alternativa para recuperar o debate, nem sempre será possível a atuação dentro dos princípios éticos-políticos, porque mesmo neste momento haveria necessidade de consenso, e as relações de poder não-paritárias desde o seu nascedouro poderiam gerar princípios igualmente não-paritários, onde as rupturas seriam elas mesmas consideradas como quebra do flair play proposto. Pode-se identificar, por exemplo, como sendo legítimos para todos os envolvidos o direito de manifestação (direito ao protesto, reunião e liberdade de expressão) e não legítimos em relação as formas de manifestação, recaindo em ações contrárias ao direito e rechaçadas novamente pelo Direito Penal, envolvendo, depredação de patrimônio público, agressão à autoridades, invasões indevidas, etc. (MIGUEL, 2014)

Neste contexto, o direito de resistir como forma de participação política da população, tem sido bastante desenvolvido em trabalhos que o correlacionam à insurreição, à revolução, ao direito de protestar, à desobediência civil, como garantias extrainstitucionais ou sociais que "muitas vezes podem fugir da legalidade (uma ocupação, uma invasão, um corte de ruta, um escrache, uma sabotagem), mas que se mostram necessários para que as instituições levem em conta reclamos que tendem a ignorar" (MIGUEL, 2014, p. 35), portanto fora da institucionalidade admitida para o agonismo.

A relação é de impacto, e para tanto poderemos utilizar de Roberto Gargarella, em trabalho que destaca que a importância da mensagem dos manifestantes inclusive pela escolha de seus elementos relacionados à liberdade de expressão, para quem devemos fazer um esforço especial para prestar atenção na mensagem que tais expressões (ainda que se apresentem violentas em um primeiro olhar) intentam enviar: 
O fato é que esses atos provocativos, perturbadores e até mesmo violentos (verbais ou não ) também podem ser - como frequentemente são - dirigidos a chamar a atenção do público a respeito de uma questão que tem sido negligenciado pelo resto da sociedade e do governo em particular ${ }^{7}$.

Em uma analise preliminar dos espaços indicados constitucionalmente para movimentação popular tem-se a associação entre o direito de reunião ${ }^{8}$ e a liberdade de expressão ${ }^{9}$, que têm sido invocados como instrumento de participação direta, embora não raro possa exceder o conteúdo institucional, compreendidos a partir de sua dimensão coletiva relacionada aos "direitos das pessoas de expandir seus pontos de vista, co o direito da sociedade de receber as expressões e informações livremente" (SANTOS; GOMES, 2014).

Desta forma, embora extrapolem o limite das regras do jogo democrático institucionalizado, as ações coletivas podem encontrar guarida na compreensão de que as dificuldades de afirmação e conquista de espaço político a partir de métodos tradicionais e disponíveis dentro do ordenamento jurídico não se mostram eficientes.

No caso Pernambucano, destacam-se as manifestações do Movimento Ocupe Estelita ${ }^{10}$ que envolvem ações articuladas envolvendo a pauta de direitos urbanos por meio das mídias sociais, destacando-se ações culturais, ocupações urbanas organizadas, vídeos envolvendo debates e sátiras relacionadas a autoridades, entre outras atividades ${ }^{11}$.

Vê-se que as manifestações sociais exteriorizadas por meio de protestos podem favorecer à construção do dissenso na democracia por representarem a tensão existente em uma decisão política, possibilitando simultaneamente aprofundamento e radicalização nos “ideais democráticos de justiça, participação e inclusão de determinados grupos na luta pelo reconhecimento e a tematização de novas demandas até então não existentes ou silenciadas" (PEREIRA, 2012, p. 80) e, nesta perspectiva, são consideradas duas estratégias, quais sejam, disruptivas ou moderadas.

Internamente, os movimentos sociais tendem a organiza-se em formas de cooperação fundadas na horizontalidade, havendo relativa igualdade entre os participantes das redes, ao

\footnotetext{
${ }^{7}$ Tradução livre: El hecho es que estos actos provocativos, disruptivos e incluso violentos (sean verbales o no), pueden también estar — como frecuentemente lo están— dirigidos a llamar la atención pública con respecto a um tema que ha sido descuidado por el resto de la sociedad y por el gobierno em particular

${ }^{8}$ XVI - todos podem reunir-se pacificamente, sem armas, em locais abertos ao público, independentemente de autorização, desde que não frustrem outra reunião anteriormente convocada para o mesmo local, sendo apenas exigido prévio aviso à autoridade competente.

${ }^{9}$ IX - é livre a expressão da atividade intelectual, artística, científica e de comunicação, independentemente de censura ou licença.

${ }^{10}$ \#OcupeEstelita, dada a sua articulação preponderante por meio das mídias sociais. Neste trabalho, ao longo do texto, o movimento será chamado de Ocupe Estelita.

${ }^{11}$ Página do movimento registrada junto ao Facebook - https://www.facebook.com/MovimentoOcupeEstelita
} 
que se afirmam:

como atores fundamentais na construção de espaços deliberativos de forma a manter uma postura crítica em relação às instituições públicas, procurando tematizar novas questões que serão analisadas e comparadas com as propostas já existentes, colaborando, assim, com o processo de aprofundamento democrático (PEREIRA, 2012, p. 81)

Neste contexto, cabe distinguir o que seria uma ação coletiva de conflito de outras formas de ação coletiva, para que possa ser compreendida a importância das ações de protestos articuladas por movimentos sociais e sua repercussão na arena pública, considerando que a primeira consiste no fato da facilitação de acesso ao centro da arena política de indivíduo que usualmente dela não participaria ao mesmo passo que ao lhe fornecer voz, permite que esses cidadãos reunidos possam ter mais influência junto à esfera pública (responsáveis pelas decisões políticas) que os eleitores (PEREIRA, 2012, p. 82).

Os indivíduos que não possuem os canais institucionais buscam atuar coletivamente de forma a pressionar o sistema político através de diferentes formas de protesto, disruptivas ou não, violentas ou não, tais como greves, ocupações, passeatas, paralisações de trânsito, criações de vírus, invasões de sites, e etc. Estas formas de ação coletiva estão inscritas na história de um determinado movimento ou de uma determinada sociedade, sendo socialmente comunicadas, permitindo que rotinas específicas sejam seguidas cada vez que um movimento social se mobilize (PEREIRA, 2012, p. 82).

O consenso, conforme a compreensão de Mouffe abordada neste trabalho, é despolitizante, e os movimentos sociais e as suas ações coletivas de conflito trazem justamente a possibilidade de execução do projeto de democracia agonística de Mouffe, embora não raro utilizem o espaço do antagonismo, dada a precariedade de espaços institucionalizados de debate e participação democrática.

No caso brasileiro está-se diante de um impasse em que de um lado encontra-se a constatação pela sociedade de que as instituições representativas vigentes não servem mais como elo dentro da proposta constitucional vigente e de outro, esbarra-se com uma sociedade alienada, na medida em que seus membros creem não compartilhar do destino da mesma sociedade na qual estão inseridos (AGRA, 2013), com o esvaziamento do espaço político.

É necessário retomar que o fato de a política pretender a canalização do conflito o alcance do consenso social, ela por si só não é capaz de esvaziar o conteúdo do político, do conflito, reforçando o consenso apenas como algo contingencial (MIGUEL, 2014, p. 26).

Neste trabalho, propõe-se apresentar em linhas gerais a atuação do Movimento 
Ocupe Estelita, dada a particularidade das ocupações urbanas, que se apresenta como uma tendência de outros movimentos similares ao redor do mundo.

\section{O MOVIMENTO OCUPE ESTELITA E A PAUTA DE DIREITOS URBANOS - O DIREITO DE RESISTIR}

O Movimento \#OcupeEstelita, como divulgado na página do facebook, corresponde a um movimento iniciado em 2012 que se autoapresenta como sendo composto por diversas identidades que se uniram em torno de um propósito, qual seja, o ideal de um crescimento urbano democrático inclusivo para a cidade do Recife em confronto ao projeto de construção de um complexo habitacional luxuoso no Cais José Estelita.

A busca pelo propósito do Ocupe Estelita é feita, precipuamente, a partir de ocupações urbanas organizadas e não violentas - realizadas em espaços públicos, em sua maioria concentradas no entorno do Cais José Estelita - como símbolo na busca pela efetivação dos direitos urbanos, com clara inspiração no movimento norte-americano do Occupy Wall Street (OWS) ${ }^{12}$, ocorrido em setembro de 2011, em Nova Iorque, e acompanha uma tendência mundial em exemplos como da Primavera Árabe, ocupações de praças na Grécia, Londres e França e ainda grandes protestos, como ocorreram no Chile, México e Brasil.

Embora recente, o movimento encontrou o ápice de sua visibilidade no ano de 2014, quando foram intensificados os movimentos de ocupação organizados bem como os debates acerca dos direitos urbanos sob o signo da proposta de crescimento urbano inclusivo. A visibilidade do movimento deveu-se, sobretudo, a divulgação nas mídias sociais (blogs, microblogs, redes sociais, etc) e às publicações veiculadas pela imprensa internacional em jornais como TheGardian, BBC News Brasil, ElPaís, considerando que por muito tempo o movimento foi ignorado pela imprensa oficial local e nacional. Em novembro do mesmo ano, o movimento recebeu a visita e o apoio de David Harvey - geográfo britânico e um dos maiores estudiosos da atualidade sobre a questão urbana.

A forma de apresentação do movimento Ocupe Estelita, entre a ocupação e o

\footnotetext{
${ }^{12}$ Também denominado \#OccupyWallStreet ou \#OWS devido a articulação do movimento realizadas por meio das redes sociais.
} 
manifesto, exteriorizada e propagada pelas mídias sociais, é um dos diferenciais do movimento, permitindo a sua análise contextualizada à "sociedade em rede" bem como o desenvolvimento de estudos voltados à superação da crise democrática a partir deste modelo. $\mathrm{O}$ direito de resistir, enquanto desejo humano de luta e não aceitação daquilo que lhe afeta em dignidade no cenário e ordem vigentes, por meio da atuação dos movimentos sociais (e também das "presenças coletivas" (SOUSA SANTOS, 2013) neste novo século é identificado por Douzinas (2015) como uma das "três novas formas de política que emergiram, respondendo às tendências e subjetividades do capitalismo tardio" em uma nova era resistência.

Autores das mais diversas áreas têm apontado as manifestações como resposta, mormente, à decadência do regime democrático representativo e o anseio por participação na política de forma direta e ativa, onde todos podem ser ouvidos e respeitados em suas subjetividades, que remonta ao discurso da democracia agonística proposto por Mouffe.

O mesmo discurso pode ser encontrado em Sousa Santos (2013) para quem os movimentos que surgiram no mundo desde 2011 representam um momento revolucionário semelhante aos que ocorreram em 1968, 1917 e 1848, com a associação da rua à simbologia de que é único espaço que não foi colonizado pelo capitalismo financeiro e, justamente por isso, as ruas e praças são os únicos espaços em que os cidadãos podem se manifestar.

De um lado, o governo não é capaz de atender as demandas sociais e volta-se pelos meios que lhe são disponibilizados - especialmente o direito - à satisfação de interesses alheios à sociedade para viabilizar o atendimento de interesses de grandes grupos econômicos, escancarando a falácia do discurso democrático apresentado à população.

Neste contexto, as ocupações urbanas organizadas surgem como alternativa ao modelo democrático posto, com suas próprias regras de atuação política, deslocando o centro do poder do Estado para toda multidão, normalmente por uma complexa articulação e propagação por meio de mídias sociais.

A escolha da mídia social como instrumento alternativo para viabilizar a comunicação é compreensível a partir da perspectiva de que as mídias usuais, como programas de televisão, rádios e jornais, fazem parte da conjuntura da manutenção do sistema político dominado por grandes grupos econômicos, tendo em vista o interesse na manipulação de canais de comunicação que atinjam a massa.

Neste contexto é que se insere o conceito de "sociedade em rede" e "era da informação" do sociólogo Manoel Castells (2010, p. 17), a partir da análise de compartilhamento e articulação da sociedade que escapa ao controle midiático das massas, e 
em decorrência deste conceito, outro, intitulado movimentos em rede, onde o Autor identifica traços comuns aos movimentos sociais da sociedade em rede, com forte articulação pela internet e o comparecimento de centenas ruas e praças, sem que haja uma centralização de liderança, com pautas diversas, mas que se repetem no mundo, e, sobretudo, onde todos para eles o espaço de autonomia que a rede representa é essencial (CASTELLS, 2013).

Repensando os movimentos sociais na era da internet, não é necessário muito esforço para associar seus conceitos cunhados por Castells ao movimento Ocupe Estelita, que se autoapresenta como sendo horizontal e sem lideranças específicas:

\begin{abstract}
É difícil definir um "nós" que dê conta da diversidade de pessoas que estão, agora, juntas nessa mesma luta. O Movimento \#OcupeEstelita é formado por advogados, arquitetos, sociólogos, artistas, professores, engenheiros, estudantes, médicos, administradores, publicitários, jornalistas, designers, antropólogos... Somos muitos. Somos qualquer um/a que deseja abraçar a luta pelo Cais. Somos qualquer um/a que deseja se erguer contra esse modelo de desenvolvimento excludente. Somos qualquer um/a que acredita num crescimento urbano democrático e inclusivo. Somos a cidade. A cidade humana, feita para as pessoas, com respeito pelas identidades, história e meio ambiente.
\end{abstract}

De outra banda, a pauta do movimento escapa ao embate clássico entre trabalhador $\mathrm{x}$ capitalismo, e passa a refletir a manifestação como forma de denúncia e resistência daqueles que são excluídos no processo de tomada de decisões que lhes afetam diretamente em sua inserção na comunidade, em seu espaço.

Neste sentido, da luta pelo espaço urbano diante da disputa com o capital, representado no movimento pelo empreendimento imobiliário Projeto Novo Recife, é o mote do Ocupe Estelita, relacionado à pauta de direitos urbanos, tendo como pano de fundo à opressão, pela não disponibilização de espaços de escuta e de diálogo com a sociedade e com as redes organizadas, enquanto que diuturnamente as mídias tradicionais expõem a população os ganhos que a consecução do projeto imobiliário trarão à cidade.

A pauta do movimento que é articulada por diversos atores consegue congregar uma associação peculiar entre o urbanismo e o direito, naquilo que se convencionou a chamar de direito à cidade, expressão criada em Henri Lefebvre (2015), retomada por David Harvey (2014), em seu livro Cidades Rebeldes, tratando da estruturação do direito à cidade à revolução urbana, onde dedica um capítulo exclusivo para tratar do movimento Occupy All Street, uma das fontes de inspiração para o movimento pernambucano Ocupe Estelita.

[...] Em Wall Street a "rua" está sendo ocupada - horror dos horrores - por 
outros! Espalhando-se de uma cidade a outra, as táticas do Occupy Wall Street consistem em ocupar um espaço público central, como um parque ou uma praça, perto dos quais se concentrem muitas alavancas do poder e, ao colocar corpos humanos nesse lugar, transformar espaço público em comuns políticos - um lugar para debates e discussões abertas sobre o que esse poder está fazendo e qual seria a melhor maneira de se opor a ele. Essa tática, notavelmente reativa nas nobres e atuais lutas que se travam na Praça Tahir, no Cairo, espalhou-se pelo mundo inteiro (Puerta do Sol, em Madri, Praça Sintagma, em Atenas, e agora nas escadarias da Catedral de São Paulo, em Londres e na própria Wall Street). Isso nos mostra que o poder coletivo dos corpos no espaço público ainda é o instrumento mais eficaz de oposição quando todos os outros meios de acesso encontram-se bloqueados.

O movimento Ocupe Estelita defende a possibilidade e necessidade de um desenvolvimento crescimento urbano democrático e inclusivo, enquanto que para participantes deste movimento, o Projeto Novo Recife apresenta um projeto para o Cais José Estelita que não se coaduna as demandas da comunidade:

O que está em jogo no novo Recife é a oportunidade de reverter a lógica de que o passado e o futuro se excluem, a lógica de que a cidade pode ser construída sem que o estado de direito seja respeitado, sem que a devida e essencial discussão democrática, coletiva, sobre os destinos do espaço público seja realizada. (ANDRADE, 2015).

Detalhar o papel de movimentos sociais assemelhados ao Ocupe Estelita na esteira da proposta da democracia agonística de Mouffe foge à proposta desta exposição, todavia, lança-se as bases para compreensão da dimensão do político na sociedade contemporânea a partir do caso pernambucano, onde a resistência é articulada diuturnamente no espaço das praças e das ruas e também das mídias sociais.

\section{CONCLUSÃO}

Superar a crise da democracia representativa se apresenta como um dos principais desafios da contemporaneidade, e não são poucas as direções que são possíveis de adotar. Para efeito desta trabalho, adotou-se a proposta da democracia de Chantal Mouffe, exposta principalmente em seu livro intitulado El Retorno del Politico, onde discute o esvaziamento do político na era da globalização e apresenta como alternativa a democracia agonística.

A crítica segue em dois sentidos. De um lado no próprio modelo de democracia ocidental, onde o espaço do político é preparado para ser o espaço do consenso ou nãoparticipação popular, e a partir daí se justifica o seu esvaziamento, e de outro, que o agonismo 
por si só não é capaz de dar conta da dimensão do conflito quanto a formação do consenso inicial, compreendido o momento em que são definidas as regras do jogo democrático.

O movimento pernambucano Ocupe Estelita apresenta-se como peculiar na medida que consegue congregar a pauta do movimento, no caso direitos urbanos, e uma distinta forma de apresentação articulada em rede, com uma composição heterogênea, mas horizontal, e com enfoque na utilização das mídias sociais para articulação de suas manifestações organizadas, especialmente as ocupações de praças e ruas da capital pernambucana.

Como antecipado, detalhar o papel de movimentos sociais assemelhados ao Ocupe Estelita na esteira da proposta da democracia agonística de Mouffe foge à proposta desta exposição, todavia, dá-se as bases para compreensão da dimensão do político na sociedade contemporânea a partir do caso pernambucano, onde a resistência é articulada diuturnamente no espaço das praças e das ruas e também das mídias sociais.

\section{REFERÊNCIAS}

AGRA, Walber de Moura. As jornadas de junho de 2013 e o seu devir. In Revista Brasileira de Estudos Constitucionais - EBET. Belo Horizonte, ano 8, nº 30, p. 671-691.

ANDRADE, Érico. Democracia Viva: por que ocupar o Estelita? Publicado no blog do Direitos Urbanos em Direitos Urbanos em 24.05.2014. Disponível em: http://direitosurbanos.wordpress.com/2014/05/24/estelita-ocupado-democracia-viva/. Acesos em 09/01/2015

BARROSO, Luis Roberto. Interpretação e aplicação da constituição: fundamentos de uma dogmática constitucional transformadora. São Paulo, Saraiva, 1996.

BINENBOJM, Gustavo. A democratização da Jurisdição Constitucional e o Contributo da Lei $\mathrm{n}^{\circ}$ 9.868/99. In: SARMENTO, Daniel (Org.). O controle de constitucionalidade e a Lei $\mathbf{n}^{0}$ 9.869/99. Rio de Janeiro: Editora Lumen Juris, 2001, p. 158, n. 44

CANFORA, Luciano. Crítica da retórica democrática. 1ed. São Paulo: Estação Liberdade, 2007. 120p.

GOMES CANOTILHO, J. J. MOREIRA, Vidal. Direito Constitucional. 6ed. Coimbra: Almedina, 1993

CASTELLS, Manuel. A era da informação: economia, sociedade e cultura. O poder da identidade. São Paulo: Paz e terra, 2010. 2 v.

CASTELLS, Manuel. Redes de indignação e esperança: movimentos sociais na era da internet. Tradução de Carlos A. Medeiros. Rio de Janeiro: Zahar, 2013. 
COSTA DOUZINAS, Da Grécia à Ucrânia: bem-vindo a nova era da resistência. Disponível em: <http://www.ihu.unisinos.br/noticias/538747-da-grecia-a-ucrania-bem-vindo-a-nova-erada-resistencia>. Acesso em: 15 de julho de 2015 [Trad. de de Pedro Lucas Dulci]

FONTES, Wagner Tenório. Neoconstitucionalismo e constitucionalização do direito in Conferência - 180 anos de Fundação dos Cursos Jurídicos no Brasil. UNICAP, setembro de 2007.

GALLO, Ronaldo Guimarães. Soberania: poder limitado (parte I) in "Revista do Senado" (conferir nome), Brasília a. 43 n. 169 jan./mar. 2006. 31-47p.

. Soberania: poder limitado (parte II) in "Revista do Senado", Brasília a. 43 n. 170 abr./jun. 2006. 25-39p.

GARGARELLA, Roberto. Un diálogo sobre la ley y la protesta social. Postdata [online]. 2007, n.12, pp. 139-170. ISSN 1851-9601.

HARVEY, David. Cidades Rebeldes: do direito à cidade à revolução urbana. São Paulo: Martins Fontes, 2014.

LEFEBVRE, Henri. O direito à cidade. 5ed. São Paulo: Centauro, 2011.

MIGUEL, Luis Felipe. Consenso e conflito na teoria democrática: para além do "agonismo". Lua Nova [online]. 2014, n.92, pp. 13-43. P. 35

MOUFFE, Chantal. El Retorno del Politico. Trad. Marco Aurelio Galmarini. Barcelona, Buenos Aires: Paidos, 1999.

Democracia, cidadania e a questão do pluralismo. Versão em espanhol deste texto foi apresentada no II Seminário Internacional Educação Intercultural, Gênero e Movimentos Sociais: identidade, diferença e mediações, promovido pela Rede Rizoma e realizado em Florianópolis (SC), entre 8 e 11 de abril de 2003. A tradução, a partir da versão em inglês, foi feita por Kelly Prudencio, doutoranda do PPGSP/UFSC.

Por um modelo agonístico de democracia. In: Revista de Sociologia e Política. $\mathrm{N}^{\mathrm{o}}$ 25, Nov. 2005. P. 11-23. Publicado em inglês como capítulo do livro The Democratic Paradox (MOUFFE, 2000a). Tradução e resumo de Pablo Sanges Ghetti; revisão da tradução de Gustavo Biscaia de Lacerda.

Por una política de identidad democrática. In: Conferencia pronunciada el 20 de março de 1999 en no seminario Globalización y diferenciación cultural, organizado por el Museu d'Art Contemporani de Barcelona y el Centre de Cultura Contemporània de Barcelona. Disponível em: < http://www.macba.cat/PDFs/chantal_mouffe_cas.pdf >. Acesso em 24 de maio de 2015.

MÜLLER, Friedrich. Quem é o povo? A questão fundamental da democracia. São Paulo: Max Limonad, 1998. 115p.

NEGRI, Antonio. O poder constituinte: ensaio sobre as alternativas da modernidade. Rio de 
Janeiro: DP\&A, 2002. 468p

; HARDT, Michael. Multidão, guerra e democracia na era do império. Rio de Janeiro: Record, 2005. 530p.

OCUPESTELITA. Site do movimento \#OcupeEstelita. Disponível em:

<http://www.ocupeestelita.com.br/pagina-exemplo/> Acesso em: 05 de janeiro de 2015

PEREIRA, Marcus Abilio. Movimentos sociais e democracia: a tensão necessária. Opin. Publica [online]. 2012, vol.18, n.1, pp. 68-87.

SOUSA SANTOS, Boaventura de. Entrevista. Folha de S. Paulo, 26 out. 2013. Entrevista concedida a Ricardo Mendonça

SANTOS, Gustavo Ferreira. Neoconstitucionalismo e Democracia in 'Revista do Senado", Brasília a. 43 n. 172 out./dez. 2006. 45-55p.

GOMES, Ana Cecília de Barros. Direito ao protesto e Constituição: parâmetros constitucionais para uma cidadania ativa. In Revista Brasileira de Estudos Constitucionais - EBET. Belo Horizonte, ano 8, nº 30, p. 587-603, set/dez - 2014. 